\title{
Response of Bitter Gourd (Momordica charantia L.) to Foliar Feeding of Micronutrient on the Growth, Yield and Quality
}

\author{
D.K. Bharati ${ }^{*}$, R.B. Verma ${ }^{1}$, V.K. Singh ${ }^{1}$, Ravi Kumar ${ }^{1}$, \\ Superna $\operatorname{Sinha}^{2}$ and S.K. Sinha ${ }^{1}$ \\ ${ }^{1}$ Department of Hort. (Veg. \& Flori.), Bihar Agricultural University, Sabour-813210, \\ Bhagalpur, India \\ ${ }^{2}$ Department of Hort. (Fruit \& Fruit tech.), Bihar Agricultural University, Sabour-813210, \\ Bhagalpur, India \\ *Corresponding author
}

A B S T R A C T

\begin{abstract}
A field study was conducted at Bihar Agricultural University, Sabour, Bhagalpur during summer season of 2011-12 to explore the possibilities of enhancing the productivity of bitter gourd with better quality by foliar application of different micronutrients in view of rising temperature. Fifteen treatments were arranged in randomized block design replicated thrice. The plot size used for raising the crop was $3.0 \mathrm{~m} \times 3.0 \mathrm{~m}$ and the spaying of micronutrients was done at 30, 40 and 50 days after sowing. The data were recorded on growth, yield and quality traits of bitter gourd. Economic feasibility of crop production was also calculated. It was observed that the foliar application of mixture of all micronutrients@100ppm being at par with boric acid @100 ppm sprayed at 30,40,50 DAS resulted in the maximum length of vines $(5.58 \mathrm{~m})$, fruit length $(25.01 \mathrm{~cm})$, fruit girth $(10.75 \mathrm{~cm})$, fruit weight/vine $(2.197 \mathrm{~kg})$, yield $(197.01 \mathrm{q} / \mathrm{ha})$ and vitamin $\mathrm{C}(64.65$ $\mathrm{mg} / 100 \mathrm{gm})$. Highest B: C ratio (2.69) was also noticed under this treatment. Therefore, on the basis of economic feasibility, it can be inferred that mixture of all micronutrients as well as boric acid @ 100ppm at 30,40 and 50 DAS is more beneficial in mitigating the problems and improving the growth, yield and quality of bitter gourd under existing climate.
\end{abstract}

\section{Introduction}

Bitter gourd (Momordica charantia L.) is one of the most important cucurbitaceous vegetables grown throughout the country for its tender fruits which are consumed as fried, cooked, and stuffed and also as pickle. Nutritionally it ranks very high especially in respect of iron and vitamin $C$. The fruit of bitter gourd are reported to have cooling, stomachic, appetising, carminative antipyretic, anthelmintic and vermifuge effect. Bitter gourd has been found highly beneficial in lowering the blood and urine sugar level. High yielding cultivars and hybrids demand more macro as well as micro nutrients. The productivity of the crop is being adversely affected in different areas due to deficiencies of micro nutrients (Bose and Tripathi, 1996). The micronutrients though required in small 
quantities are as important as macronutrients. Nutrients removal by crop depends on the nutrient availability and their absorption which is influenced by soil $\mathrm{pH}$, soil moisture and soil temperature. Micronutrients play a greater role in regulation of plant growth and yield. The agronomic adaptations like crop management, cropping system and input management like use of organic manures, use of micronutrients, use of biofertilizers etc., which are mitigations options of changing climate, require emphasis. Imbalance supply of organic inputs reduces the availability of essential micronutrients, which ultimately affect the growth, yield and quality of fruits. Boron, zinc and copper normally result in premature floral abscission that leads to failure of seed set (Brown et al., 2002). The productivity of bitter gourd $(6.87 \mathrm{t} / \mathrm{ha})$ in Bihar is comparatively lower than the national productivity (110 q/ha), which emphasizes the need of judicious and balanced use of macro as well as micronutrients together with better management practices for the improvement in the availability of nutrients. Therefore, the rational dose of micro nutrients in view of changing climate needs to be explored.

\section{Materials and Methods}

A field study was conducted at Bihar Agricultural University, Sabour, Bhagalpur during summer season of 2011-12 to explore the possibilities of enhancing the production of bitter gourd with better quality by foliar application of different micronutrients. The soil of the experimental plot was sandy loam with $\mathrm{pH} 6.8$ and the available nitrogen, phosphorus and potassium was 205.18, 36 and $196.78 \mathrm{~kg} / \mathrm{ha}$, respectively. Fifteen treatments [Boric acid 100ppm $(0.571 \mathrm{~g} / \mathrm{l})$, Zinc Sulphate 100ppm (0.246g/l), Ammonium Molybdate $50 \mathrm{ppm}(0.644 \mathrm{~g} / \mathrm{l})$, Copper Sulphate 100ppm $(0.52 \mathrm{~g} / \mathrm{l})$, Ferrus Sulphate 100ppm $(0.515 \mathrm{~g} / \mathrm{l})$, Manganese Sulphate 100ppm (0.32g/l), Mixture of all 100ppm, Commercial formulation multiplex 100ppm, Mixture of all without $\mathrm{Zn}$, Mixture of all without Mo, Mixture of all without $\mathrm{Cu}$, Mixture of all without Fe, Mixture of all without $\mathrm{Mn}$, Commercial formulation multiplex @ 4ml/1 and control (water spray only)] were arranged in randomized block design replicated thrice. The seeds of hybrid Aman Shri were shown on $10^{\text {th }}$ Feb. 2011 at a spacing of $1.5 \mathrm{~cm}^{\times} 0.50$ $\mathrm{cm}$ in a gross plot size of $3.00 \mathrm{~m} \times 3.00 \mathrm{~m}$. The recommended dose of fertilizers was applied uniformly in all the plots. The foliar applications were sprayed at the intervals of 30, 40 and 50 days after sowing (DAS). The experimental field was kept clean throughout the period of investigation by timely intercultural operations and proper plant protection measures were adopted against fruit fly and Epilachna beetle. The data on growth yield and quality attributes were recorded and were analyzed statistically the method advocated by Panse and Sukhatme (1967). Economic feasibility of the treatments was also calculated.

\section{Results and Discussion}

Foliar application of micronutrients thrice at 30,40 and 50 days after sowing resulted significantly improvement towards growth yield and quality attributes in bitter gourd as compare to control. The data displayed in Table 1 revealed that the foliar feeding of mixture of all the micronutrients $\left(\mathrm{T}_{7}\right)$ being statistically at par with boric acid @ 100ppm $\left(\mathrm{T}_{1}\right)$ recorded significantly higher length of vine $(5.58 \mathrm{~m})$, fruit length $(25.01 \mathrm{~cm})$, Fruit girth $(10.75 \mathrm{~cm})$, Fruit weight/vine $(2.197 \mathrm{~kg})$, yield $(197.01 \mathrm{q} / \mathrm{ha})$, however, number of branches/vine (24.80) and number of fruits per vine (27.40) were comparatively higher in the treatment sprayed with boric acid @100ppm. The improvement in vine length as a result of foliar feeding of micronutrients might be due to enhanced photosynthetic and other metabolic activities which lead to increase in 
various plant metabolites responsible for cell division and elongation as opined by Hatwar et al., (2003). In treatment $\mathrm{T}_{1}$ the increased number of branches/vine might be due to better sink developed by auxiliary branches to a large amount of available nutrients as reported by Maya (1996) in Sweet pepper cv. (California Wonder). The results of present experiment are in consonance with the findings of Rab and Haq (2012) in tomato. The progressive increase in number of fruits/ vine in the same treatment $\left(T_{1}\right)$ may be attributed to the fact that the boron might have helped in the absorption of water and carbohydrates metabolism (Haque et al., 2011). Foliar application of mixture of all micronutrients @ 100 ppm proved to very effective in producing higher fruit weight, longer and wider fruits attributed due to enhanced photosynthesis, accumulation of carbohydrates and favorable effects on vegetative growth which might have increased the fruits weight besides increasing the fruit size.

These results get support from the findings of Narayanamma et al., (2009) in bitter gourd. The increase in yield and yield attributes due to the foliar feeding of mixture of all micronutrients at $100 \mathrm{ppm}$ might be attributed to enhanced photosynthesis, accumulation of carbohydrates, development of cell wall and cell differentiations as they boost up overall vegetative growth, biological activity of the plants and retention of more flowers and fruits which have increased number of fruits per vine and size of fruits besides increasing yield. The production of more number of hermaphrodite flowers in watermelon by the application of calcium and boron might be due to attraction in the GA metabolism (Brantley and Warrem, 1960). These results were in agreement with the results of Patil et al., (2013) in bitter gourd. The highest dry matter production/ plant was recorded with foliar spray of mixture of all micronutrients at 100 ppm which showed parity with boron at 100 ppm this might be due to fact that the micronutrients might be responsible for enhancing the photosynthetic ability and better availability of potassium which could have helped in the translocation of metabolites from sources to sink. This was in agreement with Meenakshi and Vadivel (2003) in bitter gourd.

The TSS content in fruits differed significantly due to foliar spray of micronutrients but vitamin $\mathrm{C}$ content did not touch the level of significance. The highest TSS content (5.58 ${ }^{\mathrm{O}}$ Brix)) in fruit was obtained with foliar spray of mixture of all micronutrients $\left(\mathrm{T}_{7}\right)$ which might be due to higher concentration of NPK and micronutrients in leaves and fruits, which might have boosted the accumulation of assimilates resulting in better quality parameters (Meenakshi et al., 2007) in bitter gourd. The TSS content of tomato fruits have been shown to correlate with available boron and are increased by both foliar and soil application of boron (Sathya et al., 2010).

The similar finding has also been made by Shukla (2011) in Indian goose berry. There was a profound effect of foliar spray of micronutrients on zinc, iron and copper content in fruit. Zinc content in fruit was highest with foliar spray of zinc at $100 \mathrm{ppm}$, similarly highest copper in fruit was recorded with foliar feeding of copper at $100 \mathrm{ppm}$, which was statistically at par with the mixture of all micronutrients at $100 \mathrm{ppm}$. This may be attributed to the fact that the foliar spray of micronutrients might have increased the concentration of $\mathrm{Zn}, \mathrm{Fe}$ and $\mathrm{Cu}$ in fruits when plants were sprayed with zinc, ferrous and copper, respectively at $100 \mathrm{ppm}$ the results get full support from the findings of Aref (2011) in maize. The effect foliar application of micronutrients was more pronounced in increasing net return and benefit: cost ratio of bitter gourd. 
Table.1 Effect of foliar spray of micronutrients on growth, yield and quality attributes of bitter gourd

\begin{tabular}{|c|c|c|c|c|c|c|c|c|c|c|c|c|c|c|}
\hline $\begin{array}{l}\text { Sl } \\
\text { No } \\
\text {. }\end{array}$ & Treatment details & $\begin{array}{l}\text { Lengt } \\
\text { h of } \\
\text { vine } \\
\text { (m) }\end{array}$ & $\begin{array}{l}\text { Numbe } \\
\text { r of } \\
\text { branch } \\
\text { es /vine }\end{array}$ & $\begin{array}{l}\text { Numb } \\
\text { er of } \\
\text { fruits/ } \\
\text { vine }\end{array}$ & $\begin{array}{l}\text { Fruit } \\
\text { lengt } \\
\text { h } \\
(\mathrm{cm})\end{array}$ & $\begin{array}{l}\text { Frui } \\
\text { t } \\
\text { girth } \\
(\mathbf{c m})\end{array}$ & $\begin{array}{l}\text { Fruit } \\
\text { weigh } \\
\text { t (g) }\end{array}$ & $\begin{array}{l}\text { Fruit } \\
\text { weigh } \\
\text { t/vine } \\
\text { (kg) }\end{array}$ & $\begin{array}{l}\text { Yield } \\
\text { (q/ha) }\end{array}$ & $\begin{array}{l}\text { Vitamin C } \\
\text { content in } \\
\text { fruit } \\
\text { (mg/100g) }\end{array}$ & $\begin{array}{l}\text { TSS } \\
\text { content } \\
\text { in fruit } \\
\left({ }^{\circ} \text { brix }\right)\end{array}$ & $\begin{array}{l}\text { Zinc } \\
\text { content } \\
\text { in fruit } \\
\text { (ppm) }\end{array}$ & $\begin{array}{l}\text { Iron } \\
\text { content } \\
\text { in fruit } \\
\text { (ppm) }\end{array}$ & $\begin{array}{l}\text { Copper } \\
\text { content } \\
\text { in fruit } \\
\text { (ppm) }\end{array}$ \\
\hline 1. & $\mathrm{~T}_{0^{-}}$Control & 3.78 & 18.60 & 22.20 & 20.08 & 7.15 & 72.14 & 1.61 & 145.15 & 62.56 & 3.64 & 30.00 & 309.00 & 16.00 \\
\hline 2. & $\begin{array}{l}\mathrm{T}_{1}-\text { Boric acid } 100 \mathrm{ppm} \\
(0.571 \mathrm{~g} / \mathrm{l})\end{array}$ & 5.32 & 24.80 & 27.40 & 24.88 & 10.62 & 79.85 & 2.18 & 192.53 & 63.96 & 5.12 & 49.00 & 397.00 & 17.00 \\
\hline 3. & $\begin{array}{l}\mathrm{T}_{2^{-}} \text {Zinc sulphate } 100 \mathrm{ppm} \\
(0.246 \mathrm{~g} / \mathrm{l})\end{array}$ & 4.15 & 20.60 & 23.60 & 21.76 & 8.52 & 76.10 & 1.80 & 161.68 & 62.80 & 4.35 & 89.00 & 357.00 & 19.00 \\
\hline 4. & $\begin{array}{l}\mathrm{T}_{3}-\text { Ammonium molybdate } \\
50 \mathrm{ppm}(0.644 \mathrm{~g} / \mathrm{l})\end{array}$ & 3.98 & 19.40 & 22.60 & 20.81 & 7.98 & 74.24 & 1.68 & 150.93 & 63.10 & 3.78 & 49.00 & 382.00 & 16.00 \\
\hline 5. & $\begin{array}{l}\mathrm{T}_{4^{-}} \text {Copper sulphate } 100 \\
\operatorname{ppm}(0.52 \mathrm{~g} / 1)\end{array}$ & 4.35 & 20.00 & 23.00 & 21.34 & 8.95 & 75.62 & 1.74 & 157.94 & 63.46 & 3.86 & 40.00 & 379.00 & 22.00 \\
\hline 6. & $\begin{array}{l}\mathrm{T}_{5^{-}} \text {Ferrous sulphate } 100 \\
\mathrm{ppm}(0.515 \mathrm{~g} / \mathrm{l})\end{array}$ & 4.56 & 19.60 & 23.40 & 20.78 & 8.09 & 74.65 & 1.74 & 153.09 & 62.98 & 3.98 & 48.00 & 447.00 & 17.00 \\
\hline 7. & $\begin{array}{l}\mathrm{T}_{6^{-}} \text {Manganese sulphate } 100 \\
\operatorname{ppm}(0.32 \mathrm{~g} / \mathrm{l})\end{array}$ & 4.76 & 20.40 & 24.00 & 21.10 & 8.28 & 74.96 & 1.78 & 155.53 & 63.08 & 4.18 & 41.00 & 382.00 & 18.00 \\
\hline 8. & $\mathrm{~T}_{7}-$ Mixture of all & 5.58 & 23.80 & 26.60 & 25.01 & 10.75 & 82.41 & 2.20 & 197.01 & 64.65 & 5.58 & 75.00 & 432.00 & 21.00 \\
\hline 9. & $\mathrm{~T}_{8^{-}}$Mixture of all without $\mathrm{B}$ & 3.85 & 19.80 & 22.40 & 20.88 & 7.86 & 73.88 & 1.65 & 148.89 & 64.10 & 3.82 & 48.00 & 388.00 & 16.00 \\
\hline 10. & $\begin{array}{l}\mathrm{T}_{9^{-}} \text {Mixture of all without } \\
\mathrm{Zn}\end{array}$ & 4.10 & 20.80 & 24.40 & 22.32 & 8.81 & 77.00 & 1.87 & 168.76 & 63.68 & 4.88 & 38.00 & 412.00 & 17.00 \\
\hline 11. & $\begin{array}{l}\mathrm{T}_{10^{-}} \text {Mixture of all without } \\
\text { Mo }\end{array}$ & 4.70 & 22.00 & 25.60 & 23.12 & 9.14 & 77.85 & 2.00 & 184.42 & 63.56 & 4.56 & 46.00 & 400.00 & 19.00 \\
\hline 12. & $\begin{array}{l}\mathrm{T}_{11}-\text { Mixture of all without } \\
\mathrm{Cu}\end{array}$ & 4.95 & 21.00 & 24.60 & 22.00 & 8.75 & 76.82 & 1.89 & 166.15 & 64.00 & 3.90 & 70.00 & 427.00 & 20.00 \\
\hline 13. & $\begin{array}{l}\mathrm{T}_{12}-\text { Mixture of all without } \\
\mathrm{Fe}\end{array}$ & 4.90 & 22.60 & 25.40 & 23.05 & 9.07 & 77.56 & 1.96 & 178.56 & 63.36 & 4.96 & 56.00 & 372.00 & 20.00 \\
\hline 14. & $\begin{array}{l}T_{13}-\text { Mixture of all without } \\
\text { Mn }\end{array}$ & 4.65 & 21.40 & 24.60 & 22.78 & 8.94 & 77.24 & 1.88 & 171.66 & 63.25 & 4.76 & 72.00 & 411.00 & 20.00 \\
\hline 15. & $\begin{array}{l}\mathrm{T}_{14}-\text { Commercial } \\
\text { formulation } \\
\text { multiplex@4ml/litre }\end{array}$ & 5.00 & 22.8 & 26.60 & 24.63 & 10.52 & 79.25 & 2.11 & 188.80 & 63.25 & 5.50 & 79.00 & 422.00 & 21.00 \\
\hline & $\operatorname{Sem}( \pm)$ & 0.172 & 0.845 & 0.818 & 0.773 & 0.289 & 1.775 & 0.069 & 6.099 & 1.422 & 0.109 & 1.799 & 10.694 & 0.460 \\
\hline & C.D. at $5 \%$ & 0.50 & 2.45 & 2.37 & 2.24 & 0.84 & 5.14 & 0.201 & 17.66 & NS & 0.32 & 5.21 & 30.94 & 1.33 \\
\hline & C.V. \% & 6.50 & 6.92 & 5.80 & 6.00 & 5.63 & 4.01 & 6.42 & 6.28 & 3.88 & 4.23 & 5.63 & 4.70 & 4.29 \\
\hline
\end{tabular}


Table.2 Economic feasibility of the treatments

\begin{tabular}{|c|c|c|c|c|}
\hline SI No. & Treatment details & $\begin{array}{l}\text { Gross income } \\
\text { (Rs./ha) }\end{array}$ & $\begin{array}{l}\text { Net return } \\
\text { (Rs/ha) }\end{array}$ & $\begin{array}{l}\text { B:C } \\
\text { ratio }\end{array}$ \\
\hline 1. & $\mathrm{~T}_{0^{-}}$Control & 145150.00 & 93876.00 & 1.83 \\
\hline 2. & $\mathrm{~T}_{1}-$ Boric acid $100 \mathrm{ppm}(0.571 \mathrm{~g} / \mathrm{l})$ & 192530.00 & 138976.00 & 2.59 \\
\hline 3. & $\begin{array}{l}\mathrm{T}_{2^{-}} \text {Zinc sulphate } 100 \mathrm{ppm} \\
(0.246 \mathrm{~g} / \mathrm{l})\end{array}$ & 161680.00 & 107450.00 & 1.98 \\
\hline 4. & $\begin{array}{l}\mathrm{T}_{3} \text { - Ammonium molybdate } 50 \mathrm{ppm} \\
(0.644 \mathrm{~g} / \mathrm{l})\end{array}$ & 1509030.00 & 96924.00 & 1.79 \\
\hline 5. & $\begin{array}{l}\mathrm{T}_{4-} \text { Copper sulphate } 100 \mathrm{ppm} \\
(0.52 \mathrm{~g} / \mathrm{l})\end{array}$ & 157940.00 & 104800.00 & 1.97 \\
\hline 6. & $\begin{array}{l}\mathrm{T}_{5}-\text { Ferrous sulphate } 100 \mathrm{ppm} \\
(0.515 \mathrm{~g} / \mathrm{l})\end{array}$ & 155530.00 & 100478.00 & 1.91 \\
\hline 7. & $\begin{array}{l}\mathrm{T}_{6^{-}} \text {Manganese sulphate } 100 \mathrm{ppm} \\
(0.32 \mathrm{~g} / \mathrm{l})\end{array}$ & 1530900.00 & 102939.00 & 1.96 \\
\hline 8. & $\mathrm{~T}_{7}-$ Mixture of all & 197010.00 & 143646.00 & 2.69 \\
\hline 9. & $\mathrm{~T}_{8}-$ Mixture of all without $\mathrm{B}$ & 148890.00 & 95554.00 & 1.79 \\
\hline 10. & $\mathrm{~T}_{9}-$ Mixture of all without $\mathrm{Zn}$ & 168760.00 & 115559.00 & 2.17 \\
\hline 11. & $\mathrm{~T}_{10^{-}}$Mixture of all without Mo & 184420.00 & 131175.00 & 2.46 \\
\hline 12. & $\mathrm{~T}_{11^{-}}$Mixture of all without $\mathrm{Cu}$ & 166150.00 & 112750.00 & 2.11 \\
\hline 13. & $\mathrm{~T}_{12}$ - Mixture of all without $\mathrm{Fe}$ & 176560.00 & 123036.00 & 2.30 \\
\hline 14. & $\mathrm{~T}_{13^{-}}$- Mixture of all without $\mathrm{Mn}$ & 171660.00 & 118132.00 & 2.21 \\
\hline 15. & $\begin{array}{l}T_{14^{-}} \text {Commercial form. } \\
\text { multiplex@4ml/litre }\end{array}$ & 188800.00 & 134262.00 & 2.46 \\
\hline
\end{tabular}

The net returns and benefit: Cost ratios were significantly higher with foliar spray of mixture of all micronutrients at $100 \mathrm{ppm}$ followed by foliar spray of boron at $100 \mathrm{ppm}$ (Table 2). The increase in net return and benefit: cost may be due to increased growth yield contributing parameters and yield of bitter gourd. The results are in agreement with the findings of Kumar et al., (2010) in cauliflower.

Therefore, on the basis of economic feasibility, it can be inferred that the foliar spray of mixture of all micronutrients as well as boric acid @ 100ppm at 30, 40 and 50 DAS is more beneficial in mitigating the problems and improving the growth, yield and quality of bitter gourd.

\section{Acknowledgement}

The authors are thankful to Department of Horticulture (Vegetable and Floriculture),
Bihar Agricultural University, Sabour, Bhagalpur (Bihar) for providing all the required facilities for the present work.

\section{References}

Aref Farshid 2011. Iron, Coper and manganese concentration in maize leaf as influenced by soil and foliar application of zinc sulphate and boric acid. International $J$. of Academic Research, 3 (2)

Bose U S and Tripathi S K 1996. Effect of micronutrients on growth, yield and quality oftomato cv. Pusa Ruby in M.P. Crop Research, 12:61-64.

Brantley B B and Warren G F 1960. Effect of nitrogen on flowering, fruiting and quality of the watermelon. Proc. of American Society Horticulture Science, 75: 644-649.

Brown P H, Bellaloui N, Wimmer M A, Bassil E S, Ruiz J, Hu H, Pfeffer H, 
Dannel F and Romheld V 2002. Boron in plant biology. Plant Biology, 4, 205223

Haque M E, Paul A K and Sarkar J R 2011. Effect of nitrogen and boron on the growth and yield of tomato (Lycopersicon esculentum M.) EJBSM, 2: 277-282.

Kumar P, Suresh Bhagwati R, Choudhary K V, Devi Preema and Ronya T 2010. Effect of boron and molybdenum on growth, yield and quality of cauliflower in mid altitude condition of Arunachal Pradesh. Vegetable Science, 37 (2): 190-193.

Maya P 1996. Studies on the effect of sapling cum nitrogen and phosphorus on growth and quality of sweet pepper cv. California Wonder. M. Sc. (Ag.) Thesis submitted to Tamilnadu Agric. Univ., Coimbatore.

Meenakshi N, Vadivel E and Kavitha M 2007. Response of bitter goud on fruit yield and quality traits as influenced by fertigation levels. The Asian J. of Horticulture, 2 (2): 126-130.

Narayanamma M, Radha Rani K, Kameswari Lalitha P and Reddy RVSK 2009.
Effect of foliar application of micronutrients on the yield components, yield and nutrient content of bitter gourd. The Orissa J. Horticulture. 37 (2):

Patil B C, Padanad A, Laxman Yashvant, Kumar K H, Gopali JB and Shetty Soumiya 2013. Response of foliar application of micronutrients on yield and economics of bitter gourd (Momordica charantia L.). The Orissa J. Horticulture, 18 (2): 677-679.

Rajasree G and Pillai G R 2012. Effect of nitrogen nutrition on fruit quality and shelf-life of cucurbitaceous vegetable bitter gourd. J. Plant Nutrition, 35 (8): 1139-1153.

Sathya S, Mani S, Mahendran P P, Arulmozhiselvan K 2010. Effect of application of boron on growth, quality and fruit yield of PKM, Tomato. Indian J. Agric. Res., 44:274-280.

Shukla A K 2011. Effect of foliar application of alcium and boron on growth, productivity and quality of India gooseberry (Emblica officinalis). Indian J. of Agric. Sci., 81 (7):628-632.

\section{How to cite this article:}

Bharati, D.K., R.B. Verma, V.K. Singh, Ravi Kumar, Superna Sinha and Sinha, S.K. 2018. Response of Bitter Gourd (Momordica charantia L.) to Foliar Feeding of Micronutrient on the Growth, Yield and Quality. Int.J.Curr.Microbiol.App.Sci. 7(02): 2341-2346. doi: https://doi.org/10.20546/ijcmas.2018.702.284 